\title{
Okončanje HIV-epidemije u Hrvatskoj
}

\section{Ending the HIV epidemic in Croatia}

\author{
Josip Begovac \\ Medicinski fakultet Sveučilišta u Zagrebu i Klinika za infektivne bolesti „Dr. Fran Mihaljević”
}

Keywords:

HIV

Pre-exposure prophylaxis

Ključne riječi:

HIV

predekspozicijska profiaksa

Primljeno: 11.4.2019.

Received: 11.4.2019.

Prihvaćeno: 13.5.2019.

Accepted: 13.5.2019.

\section{$\checkmark$ Contact information:}

Josip Begovac

Medicinski fakultet Sveučilišta u Zagrebu

Klinika za infektivne bolesti, Dr. Fran Mihaljević

10000 Zagreb, Croatia

E-mail: josip.begovac@gmail.com

Danas je tema okončanja HIV-epidemije u svijetu aktualna i predstavlja jedan ambiciozni i po svemu sudeći ostvarivi cilj ${ }^{[1,2]}$. Inicijativa se oslanja na ključna znanstvena dostignuća u prevenciji zaraze HIV- om, dijagnostici, liječenju i skrbi. Svakako treba istaći nasumične kliničke pokuse PROUD i IPERGAY koji su pokazali da je predekspozicijska profilaksa efikasna u smanjivanju šanse zaraze HIV-om u populaciji muškaraca koji imaju spolne odnose s drugim muškarcima (MSM) ${ }^{[3,4]}$. Istraživanja PARTNER1 i PARTNER2 su pokazala da nemjerljivost znači nezaraznost (engl. $U=U$, Undetectable $=$ Untransmittable $)^{[5,6]}$. Rezultati brojnih kliničkih ispitivanja doveli su do značajnog napretka u liječenju HIV-infekcije, tako da osoba koja živi s HIV-om i koja se pravilno liječi i redovito uzima terapiju može očekivati normalan životni vijek.

Danas raspolažemo alatima i znanjem kako suzbiti HIV-epidemiju. Alati i znanja uključuju:

1. dijagnosticiranje svih osoba zaraženih HIV-om što je moguće ranije nakon infekcije;

2. brzo i učinkovito uključivanje u skrb i započinjanje antiretrovirusne terapije kako bi se postigla i održala nemjerljiva količina virusa u krvi;
\end{abstract}

3. prevencija zaraze HIV-om kod osoba pod povećanim rizikom, uključujući uporabu predekspozicijske profilakse (PrEP); i

- povećanje testiranja na HIV i druge spolno prenosive bolesti

- ciljano testiranje u zajednici kod populacije muškaraca koji imaju spolne odnose s drugim muškarcima

- demedikalizacija testiranja, brzi testovi, samotestiranje

4. brzo otkrivanje i adekvatan odgovor na pojavljivanje novih klastera zaraze HIV-om radi daljnjeg smanjenja novih infekcija

U Hrvatskoj smo ostvarili niz preduvjeta za okončanje HIV-epidemije, uključujući poznavanje lokalne epidemije. Mi imamo izvrsno praćenje epidemije s dostupnim preciznim podacima o broju zaraženih, broju uključenih u skrb, broju osoba koji primaju antiretrovirusne lijekove i broju koji imaju nemjerljivu viremiju. Znamo da nam je osnovni problem otkrivanje osoba koje su zaražene, a koje ne znaju za svoj HIV-status. Naše procjene su da bi ta brojka mogla biti oko 20-
25\% od ukupnog broja osoba koja živi s HIV-om, što bi značilo da u Hrvatskoj živi oko 400-500 osoba koje ne znaju da su zaražene HIV-om.

Procjenjujemo da se u jednoj kalendarskoj godini 80-tak ljudi zarazi HIV-om u RH. Iako se još uvijek HIV-infekcija u Hrvatskoj otkriva relativno kasno imamo uspješne programe testiranja u zajednici (Checkpoint i Iskorak) u kojima se HIV-infekcija otkriva ranije. Imamo i razvijenu mrežu centara za dobrovoljno i anonimno testiranje u kojima se zaraza HIV-om također otkriva u ranijoj fazi. U posljednje vrijeme imamo i projekt testiranja na spolne bolesti u populaciji MSM koji se ostvaruje u „Popodnevnoj Klinici“ u Klinici za infektivne bolesti u Zagrebu. Navedena testiranja također omogućuju ranije otkrivanje zaraze HIVom. Naša prva iskustva u primjeni predekspozicijske profilaksa (PrEP) također ukazuju da se kroz probir za PrEP može rano otkriti HIV-infekcija. Od 100-tinjak osoba u kojih smo napravili probir za PrEP, otkrili smo 6 novih HIV-infekcija. Svi naši pokazatelji ukazuju na izvrsnu koordinaciju centara za testiranje na HIV (bilo u zajednici ili u zdravstvenim ustanovama) i Klinike za infektivne bolesti u Zagrebu tako da je uključiva- 
nje u skrb nakon postavljene preliminarne dijagnoze HIV-infekcije vrlo brzo (većinom unutar 7 dana). Isto tako u Klinici postoji sada već dugogodišnja praksa da osobe zaražene HIV-om već kod prvog pregleda dobiju antiretrovirusne lijekove. Zadržavanje u skrbi je odlično i suradljivost $s$ liječenjem je velika. Također pružamo odgovarajuću psihosocijalnu potporu osobama koje žive s HIV-om, kao i obiteljima i partnerima koji su pogođeni HIV-om. Danas u Hrvatskoj raspolažemo dobrim izborom antiretrovirusnih lijekova, novi lijekovi dospijevaju na Listu lijekova Hrvatskog zavoda za zdravstveno osiguranje relativno brzo nakon što su odobreni od strane Europske agencije za lijekove. Nadalje, u Klinici za infektivne bolesti u Zagrebu postoji mogućnost genotipizacije HIV-a i definiranje „klastera infekcije u realnom vremenu“ što može omogućiti ranu intervenciju u suzbijanju širenja HIV-infekcije.

Dakle, u Hrvatskoj postoji niz preduvjeta za uspješno suzbijanje HIV-infekcije i Hrvatska ima šansu biti među prvim državama u Europi koja može okončati HIV-epidemiju (engl. „end of HIV/AIDS“). Ipak, navedeni cilj nije lako postići. Nisu potrebna samo sredstva za lijekove, testove i različite laboratorijske analize već i infrastruktura i stručno osoblje koji će aktivno sudjelovati u ostvarivanju navedenog cilja. Potrebno je širiti programe testiranja u zajednici izvan Zagreba i razmotriti mogućnost uvođenja „kućnog“ testiranja na HIV. Potrebno je proširiti primjenu PrEP-a. Jedna naša procjena ukazuje da bi mogli imati populacijski učinak na smanjenje HIV-epidemije ako bi u Hrvatskoj oko 700 osoba uzimalo PrEP. Potrebno je učiniti dostupnim testiranje i liječenje „klasičnih" spolnih bolesti (sifilis, gonoreja, infekcija klamidijom) osobama koje su pod povećanim rizikom (prvenstveno MSM). Stigma je još uvijek problem, ali nas ona ne smije obeshrabriti u provođenju prevencije i liječenja. I u konačnici svakako je potrebno zadržati sve dosadašnje aktivnosti koje su dovele do toga da u RH nikad nismo imali razvijenu HIV-epidemiju. Naša epidemija HIV-infekcije je ostala na niskoj razini, a od 2015.g. čak bilježimo blagi pad broja novodijagnosticiranih osoba. Usprkos navedenim uspjesima potreban je dodatni napor za okončanje HIV-epidemije, a za ostvarivanje navedenog cilja svakako je potrebna potpora šire zajednice.

\section{LITERATURA}

${ }^{[1]}$ UN. General Assembly (session 70/266). Political Declaration on HIV and AIDS : On the Fast- Track to Accelerate the Fight Against HIV and to End the AIDS Epidemic by 2030. Resolution adopted by the General Assembly on 8 June 2016.

${ }^{[2]}$ Fauci AS, Redfield RR, Sigounas G, Weahkee MD, Giroir BP. Ending the HIV Epidemic: A Plan for the United States. JAMA 2019;321:844-45.

${ }^{[3]}$ Molina JM, Capitant C, Spire B i sur. On-Demand Preexposure Prophylaxis in Men at High Risk for HIV-1 Infection. N Engl J Med 2015;373:2237-46.

${ }^{[4]}$ McCormack S, Dunn DT, Desai M i sur. Pre-exposure prophylaxis to prevent the acquisition of HIV-1 infection (PROUD): effectiveness results from the pilot phase of a pragmatic open-label randomised trial. Lancet 2016;387:53-60.

${ }^{[5]}$ Rodger AJ, Cambiano V, Bruun T i sur. Sexual Activity Without Condoms and Risk of HIV Transmission in Serodifferent Couples When the HIV-Positive Partner Is Using Suppressive Antiretroviral Therapy. JAMA 2016;316:171-81.

${ }^{[6]}$ Rodger AJ, Cambiano V, Bruun T i sur. Risk of HIV transmission through condomless sex in serodifferent gay couples with the HIV-positive partner taking suppressive antiretroviral therapy (PARTNER): final results of a multicentre, prospective, observational study. Lancet 2019;393:2428-38. 